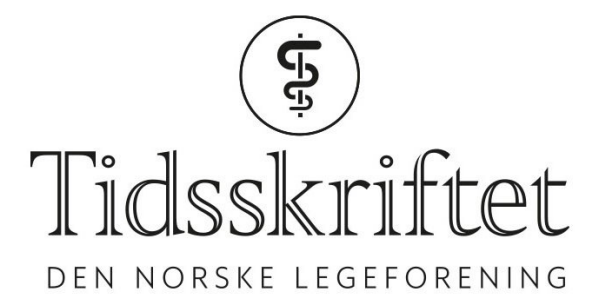

\title{
Global health financing: Priority to poor people or poor countries?
}

GLOBAL HELSE

\section{KRISTINE HUSØY ONARHEIM}

E-mail: kristine.onarheim@uib.no

Kristine Husøy Onarheim (born 1987), PhD candidate at the Department of Global Public Health and Primary Health Care, University of Bergen. She works as a medical doctor at Ålesund Hospital, Møre og Romsdal Hospital Trust.

The author has completed the ICMJE form and reports no conflicts of interest.

\section{UNNI GOPINATHAN}

Unni Gopinathan (born 1986), postdoctoral fellow in global health policy at the Institute of Health and Society, Faculty of Medicine, University of Oslo, and the Division for Health Services, Norwegian Institute of Public Health.

The author has completed the ICMJE form and reports no conflicts of interest.

Global health initiatives have long focused on the health of poor people in poor countries. Changes in demographic, economic, and health patterns challenge our understanding about where to direct our attention. Most of the world's poor now live in middle-income countries. How should this affect the distribution of development assistance for health? Should we give priority to poor people or poor countries?

The Sustainable Development Goals were adopted by the United Nations in September 2015. These goals have broadened the global development agenda in general, and the global health agenda more specifically (1). Goal 3 -Ensure healthy lives and promote well-being for all at all ages - is devoted to health.

An objective under this goal is to achieve universal health coverage, including financial risk protection, access to quality essential health-care services and access to safe, effective, quality and affordable essential medicines and vaccines for all. Moving towards universal health coverage will require an increase in health financing - both domestic and external - from current levels (2). External financing is commonly referred to as 'health aid' or 'development assistance for health' (3). Though health spending in low- and middle-income countries is mainly financed by government budgets and private financing where patients pay directly to healthcare providers (also known as out-of-pocket payments), development assistance also plays a role. The absolute amount reached USD 36.4 billion in 2015 (4).

The first years of the millennium (2000-2009) have been described as the 'golden era' of global health, where development assistance for health increased by $11.3 \%$ per year through increased contributions from high-income countries as well as philanthropic donors (4). Since 2010 the increase has faltered, with an annual growth of $1.2 \%$ between 2010 and 2015 (4). The implications for poor people in countries with low domestic spending on health 
care deserve further scrutiny. When resources are limited, it is crucial to discuss where and how to best invest resources for health.

The primary objective of development assistance for health could be seen as to improve the health of the world's poorest, and that funding should aim to reach populations with the greatest need. This is particularly important with respect to universal health coverage. The poorest populations are often those who suffer the most from lack of access to health care, both due to poorer health and a greater risk of catastrophic out-of-pocket expenses. The latter refers to medical expenses that push households below, or further below, the poverty line (5).

In this article, we draw upon recent literature examining the altered classification of countries by income level, and the corresponding changes in the geographic distribution of the world's poorest. We then discuss implications for how development assistance for health should be distributed to finance universal health coverage.

\section{The majority of the world's poorest do not live in the poorest countries}

Recent developments at country level challenge traditional assumptions about the geographic location of the world's poorest populations. The landscape has drastically changed since 1990 . Almost $75 \%$ of the world's poorest now live in middle-income countries (Figure 1 and Table 1$)(6,7)$. The altered distribution can partially be explained by economic development at country level.

Low-income countries

\section{Middle-income countries}

\section{Proportion(\%)}

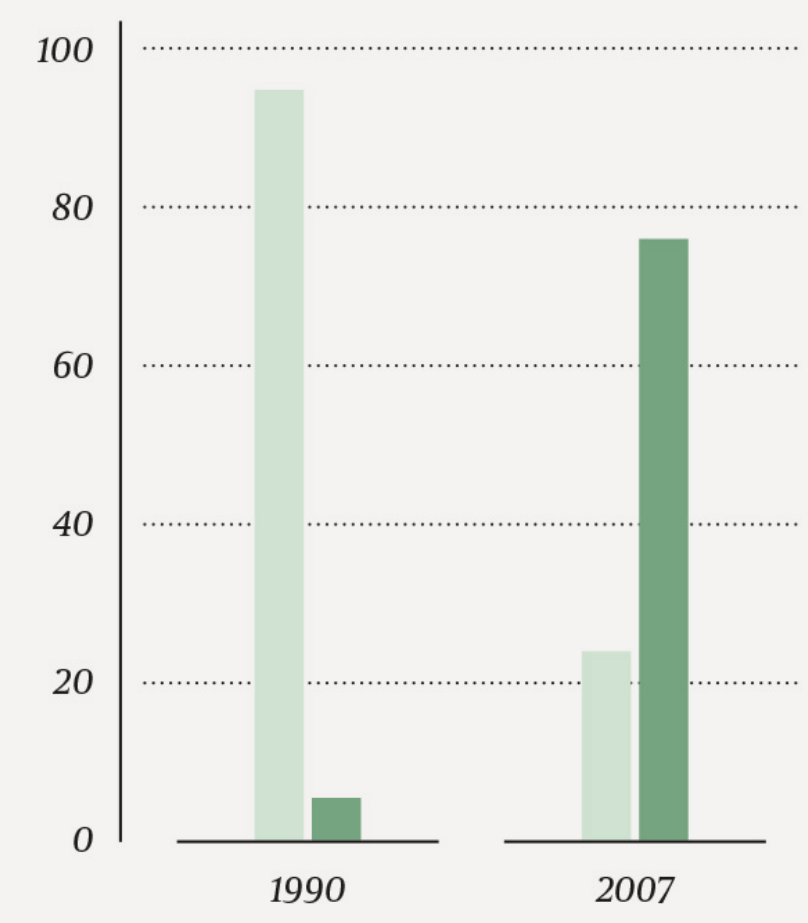

Figure 1 Proportion of the world's poorest living below USD 1.25 a day in low-and middle-income countries (6). 
Table 1

Health and poverty in low-, middle- and high-income countries in 2013 (7).

\begin{tabular}{|lccc|}
\hline & $\begin{array}{c}\text { Life expectancy } \\
\text { at birth (years) }\end{array}$ & $\begin{array}{c}\text { Infant mortality rate } \\
\text { (infant deaths/100o live } \\
\text { births) }\end{array}$ & $\begin{array}{c}\text { \% of population in } \\
\text { poverty (USD1.90 a } \\
\text { day, 2011 PPP) }\end{array}$ \\
\hline High-income countries & 80.4 & 4.9 & 0.3 \\
\hline $\begin{array}{l}\text { Middle-income } \\
\text { countries }\end{array}$ & 70.7 & 32.6 & 9.8 \\
\hline Low-income countries & 61.1 & 56.4 & 46.2 \\
\hline
\end{tabular}

Between 1990 and 2010 many countries, including populous countries such as China, Nigeria, India, Indonesia, and Pakistan, transitioned from low-income to middle-income country status. In spite of economic development and improvements in average income per capita, the absolute number of poor people fell less than expected in most of these countries (8).

Now, $90 \%$ of the world's poorest are concentrated in approximately 20 countries, and almost half of these are middle-income countries previously classified as low-income countries (8). When countries have transitioned to middle-income status, they also transition away from support from global health initiatives such as GAVI (formerly known as the Global Alliance for Vaccines and Immunization) and the Global Fund $(6,9)$.

\section{Distributing global health financing fairly}

From one perspective, what should matter to development assistance is 'poor people', irrespective of their geographic location (10). Accordingly, middle-income countries should be eligible for development assistance for health (10-12). Further, the classification itself has been criticised as the threshold is somewhat arbitrary (12-14); countries above or below the same threshold differ widely with respect to health needs and the capacity to address them $(9,10)$.

On the other hand, obtaining middle-income status reflects a country's increasing internal capacity to respond to its health needs, in some cases entirely without external support. The financing gaps are thus likely to be greater for low-income countries (13). Recent estimates from the World Health Organization support a view that the poorest countries are in most need of external health financing (15). The study estimated the additional investments needed to achieve the health-related sustainable development targets in low- and middleincome countries, and identified large financing gaps.

Many countries will depend on continued external financial support to strengthen their health systems. Particularly, fragile and conflict-ridden states with weak health and welfare institutions will continue to need development assistance for health (15). Further, the study argued that middle-income countries are 'well equipped to self-finance the investment', and that the largest financing gaps are in low-income countries (15), indicating that development assistance for health should primarily be directed to these countries.

Despite gaps in healthcare financing, most countries have the capacity to increase investments in health systems (15). Spending on health care is predicted to progress faster in upper-middle-income countries, while health spending in low-income countries is estimated to remain low (16).

This is an additional argument for giving more priority to low-income countries. Even if they experience economic growth, many are far from spending the recommended $5 \%$ of gross domestic product on health care (17). However, middle-income countries may have difficulties in the short term in mobilizing resources to replace recent bilateral, multilateral and philanthropic support. It is therefore crucial to consider potential harms induced by shifting resources away from middle-income countries. 
Views diverge about whether middle-income countries, due to their share of the world's poorest populations, should continue to be eligible for development assistance for health. Scholars have proposed that middle-income countries should not be automatically excluded from development assistance for health per se, but that each country must be considered on a case-by-case basis, given their heterogeneity $(10,11,13)$.

More recently, efforts have been made to systematically assess criteria guiding the allocation of development assistance for health. Two overarching criteria for distribution have been suggested $(13,18)$ : 'need' and 'effectiveness'. The 'need' criterion prescribes that development assistance for health (or aid more generally) should be allocated to countries with the greatest need. This could be measured using a range of indicators, including gross national income per capita, under-five mortality rate, the burden of disease, or income inequality.

The 'effectiveness' criterion prescribes that aid should be allocated to countries where the development gains, such as improvements in health, are likely to be the greatest. A simulation of the implications of eleven criteria identified that low-income countries would receive most development assistance for health given a needs-based approach linked to domestic capacity to address health needs (9). Upper-middle-income countries would receive a greater share of development assistance for health if an income-inequality criterion was given greater weight (9).

Depending on countries' ability to pay, as measured by gross national income per capita, should we ask whether middle-income countries ought also to contribute to financing global health (13). Some of these countries, such as China, India, and South Africa, have for some time provided aid to other countries (19). These and other countries can play a significant role in the efforts to strengthen financing of health challenges, particularly those that require global collective action.

\section{Global public goods}

Since the Ebola outbreak in 2014-15, academia and policymakers have paid increasing attention to the need for global financing arrangements to strengthen production of global public goods $(20,21)$.

According to the classic definition, global public goods are considered to be goods that are both non-excludable and non-rivalrous (22). When a good is non-excludable, no person (or country) can be prevented from enjoying the benefits of the good once it becomes available. When a good is non-rivalrous, one person's consumption does not diminish the quantity available to others. For example, the reduced risk of infectious diseases is considered a classic global public good - the benefits are both non-rivalrous and non-excludable to the global population.

Initiatives to improve national and global preparedness to protect against future epidemics and pandemics are also referred to as efforts to strengthen global health security (23). The recent establishment of the Coalition for Epidemic Preparedness (CEPI) is an example of a shared global arrangement to finance the achievement of this global public good (20).

Collective financing to produce global public goods and strengthen global health security complicates our discussion of the allocation of global health financing. So far we have primarily discussed how financing and development assistance for health should be targeted to meet the healthcare needs of populations in low- and middle-income countries.

The World Health Organization's estimates to achieve Sustainable Development Goal 3 offer some guidance for financing of global public goods, as in-country epidemic and pandemic preparedness relates to global financing of other health needs (15). The study suggests that three-quarters of the investments to achieve the health targets should be in health workforce and infrastructure, including services that strengthen preparedness against epidemics and pandemics (15). Thus, promotion of global public goods and global health 
security must not entail diversion of resources away from broader efforts to strengthen general health services, but rather underpin these efforts. However, achieving this synergy will also require careful thinking about how to manage potential tensions (24).

\section{A shared responsibility}

As countries progress to achieve the health-related development goals, low-income countries will, in spite of increased domestic financing, still face large financing gaps which require external financing $(15,17)$.

The majority of the world's poorest now live in middle-income countries, which should have higher domestic capacity and the ability to fund universal health coverage themselves. Yet, large within-country inequalities in income, health and other indicators of well-being represent huge challenges to these countries, which suggests that their transition from external support should be gradual. The increasing capacities of middle-income countries present opportunities to strengthen cooperation and mechanisms to finance shared health challenges.

The main impetus for promoting universal health coverage and addressing other global health challenges should not be self-interest. Rather, our efforts should stem from the fact that it is unfair and unacceptable in a globalised and interconnected world that income levels and poverty still determine people's opportunities to lead long and healthy lives.

\section{REFERENCES:}

1. United Nations. Transforming our world: the 2030 agenda for sustainable development. New York: United Nations, 2015. https://sustainabledevelopment.un.org/post2015/transformingourworld (20.10.2017).

2. Røttingen JA, Ottersen T, Ablo A et al. Shared Responsibilities for Health: A Coherent Global Framework for Health Financing, Final Report of the Centre on Global Health Security Working Group on Health Financing. London, UK: Chatham House, 2014.

https://www.chathamhouse.org/sites/files/chathamhouse/field/field_document/20140521HealthFinan cing.pdf(20.10.2017).

3. Moon S, Oluwatosin O. Development Assistance for Health: Critiques and Proposals for Change, Centre on Global Health Security Working Group Papers. London: Chatham House, 2013. https://www.chathamhouse.org/sites/files/chathamhouse/public/Research/Global\%2oHealth/o413_de vtassistancehealth.pdf(20.10.2017).

4. Dieleman JL, Schneider MT, Haakenstad A et al. Development assistance for health: past trends, associations, and the future of international financial flows for health. Lancet 2016; 387 : 2536 - 44 . [PubMed][CrossRef]

5. World Health Organization. World Bank. Tracking universal health coverage: first global monitoring report, 2015.

http://apps.who.int/iris/bitstream/10665/174536/1/9789241564977_eng.pdf?ua=1 (20.10.2017).

6. Sumner A. Where Do The Poor Live? World Dev 2012; 40: 865 - 77. [CrossRef]

7. World Bank. World Bank Open Data. https://data.worldbank.org/ (10.08.2017).

8. Sumner A. Where Do the World's Poor Live? A New Update. Institute of Development Studies, 2012. http://www.ids.ac.uk/files/dmfile/Wp393.pdf(20.10.2017).

9. Ottersen T, Moon S, Røttingen JA. Distributing development assistance for health: simulating the implications of 11 criteria. Health Econ Policy Law 2017; 12: 245 - 63. [PubMed][CrossRef]

10. Kanbur R, Sumner A. Poor countries or poor people? Development assistance and the new geography of global poverty. J Int Dev 2012; 24: 686 - 95. [CrossRef]

11. Glassman A, Duran D, Sumner A. Global Health and the New Bottom Billion: What do Shifts in Global Poverty and Disease Burden Mean for Donor Agencies? Glob Policy 2013; 4: 1 - 14. [CrossRef] 
12. Glennie J. The Role of Aid to Middle-Income Countries: A Contribution to Evolving EU

Development Policy. London: Overseas Development Institute, 2011.

https://www.odi.org/sites/odi.org.uk/files/odi-assets/publications-opinion-files/7189.pdf(20.10.17).

13. Ottersen T, Moon S, Røttingen J-A. The challenge of middle-income countries to development assistance for health: recipients, funders, both or neither? Health Econ Policy Law 2017; 12: 265 - 84 [PubMed][CrossRef]

14. Sumner A. The world's two new middles. Growth, precarity, structural change, and the limitations of the special case. WIDER Working Paper 2016/34. 2016.

https://www.wider.unu.edu/sites/default/files/wp2016-34.pdf(20.10.2017).

15. Stenberg K, Hanssen O, Edejer TT et al. Financing transformative health systems towards achievement of the health Sustainable Development Goals: a model for projected resource needs in 67 low-income and middle-income countries. Lancet Glob Health 2017; 5: e875 - 87. [PubMed][CrossRef]

16. Global Burden of Disease Health Financing Collaborator Network. Future and potential spending on health 2015-40: development assistance for health, and government, prepaid private, and out-ofpocket health spending in 184 countries. Lancet 2017;389: 2005-30. [PubMed][CrossRef]

17. Mcintyre D, Meheus F, Røttingen J-A. What level of domestic government health expenditure should we aspire to for universal health coverage? Health Econ Policy Law 2017; 12: 125 - 37. [PubMed][CrossRef]

18. Ottersen T, Kamath A, Moon S et al. Development assistance for health: Quantitative allocation criteria and contribution norms. London: Chatham House, 2014.

https://www.chathamhouse.org/publications/papers/view/197643(20.10.2017).

19. OECD. New partners for development. From Aid to Development - New partners for development 2012. http://www.oecd-ilibrary.org/error/authentication/o111101ecoog.pdf;jsessionidat7uqh7rl6bqg.x-oecd-live-o2 (20.10.2017).

20. Brende B, Farrar J, Gashumba D et al. CEPI-a new global R\&D organisation for epidemic preparedness and response. Lancet 2017;389: 233-5. [PubMed][CrossRef]

21. Yamey G, Schäferhoff M, Aars OK et al. Financing of international collective action for epidemic and pandemic preparedness. Lancet Glob Health 2017; 5: e742 - 4. [PubMed][CrossRef]

22. Samuelson PA. The Pure Theory of Public Expenditure. Rev Econ Stat 1954;36:387 - 9. [CrossRef]

23. Heymann DL, Chen L, Takemi K et al. Global health security: the wider lessons from the west African Ebola virus disease epidemic. Lancet 2015;385:1884 - 901. [PubMed][CrossRef]

24. Ooms G, Beiersmann C, Flores W et al. Synergies and tensions between universal health coverage and global health security: why we need a second 'Maximizing Positive Synergies' initiative. BMJ Glob Health 2017; 2: eooo217. [PubMed][CrossRef]

Published: 28 November 2017. Tidsskr Nor Legeforen. DOI: 10.4045/tidsskr.17.0715

Received 22.8.2017, first revision submitted 9.10.2017, accepted 20.10.2017.

(C) The Journal of the Norwegian Medical Association 2020. Downloaded from tidsskriftet.no 